\title{
PENGARUH KUALITAS LAYANAN TERHADAP KEPUASAN KONSUMEN MEMBELI TIKET PADA AGEN JASA MASKAPAI PENERBANGAN PT. GARUDA AIRLINES DI KOTA PALU
}

\author{
Henny Puspitasari \\ Rosida P. Adam \\ H. Syamsul Bahri Dg. Parani \\ Jurusan Manajemen, Fakultas Ekonomi, Universitas Tadulako \\ Email: puspitasari184@gmail.com
}

\begin{abstract}
This study aims to examine the simultaneous and partial influence of tangibles (X1), reliability $(X 2)$, responsiveness (X3), assurance (X4), and empathy (X5) on customer satisfaction (Y) in Garuda Airlines agent in Palu City. The type of research is descriptive-causal. Sampling technique is purposive sampling method. The results show that the dimensions of service quality consisting of physical evidence, empathy, reliability, responsiveness, and assurance simultaneously have a significant influence on customer satisfaction of buying tickets at Garuda Airline service agents. Partially, all the dimension of service quality have significant influence on the customer satisfaction of buying tickets at The Garuda airline service agent in Palu City.
\end{abstract}

Keywords: quality of service, consumer satisfaction

\begin{abstract}
Abstrak
Penelitian ini bertujuan untuk mengetahui pengaruh secara serempak dan parsial dari tangibles (X1), reliability (X2), responsiveness (X3), assurance (X4), empathy (X5) terhadap kepuasan konsumen (Y) yang melakukan pembelian tiket pada agen jasa maskapai PT.Garuda Airlines di Kota Palu. Jenis penelitian ini yaitu jenis penelitian deskriptif kausal. Teknik penarikan sampel menggunakan metode purposive sampling Hasil penelitian menunjukkan bahwa dimensi kualitas layanan yang terdiri dari Bukti Fisik, Empati, Kehandalan, Daya Tanggap, dan Jaminan secara serempak berpengaruh signifikan terhadap kepuasan konsumen membeli tiket pada agen jasa maskapai penerbangan PT. Garuda Airlines. Dimensi Bukti Fisik berpengaruh signifikan terhadap kepuasan konsumen membeli tiket pada agen jasa maskapai penerbangan PT. Garuda Airlines. Dimensi Empati berpengaruh signifikan terhadap kepuasan konsumen membeli tiket pada agen jasa maskapai penerbangan PT. Garuda Airlines. Dimensi Kehandalan berpengaruh signifikan terhadap kepuasan konsumen membeli tiket pada agen jasa maskapai penerbangan PT. Garuda Airlines. Dimensi Daya Tanggap berpengaruh signifikan terhadap kepuasan konsumen membeli tiket pada agen jasa maskapai penerbangan PT. Garuda Airlines. Dimensi Jaminan berpengaruh signifikan terhadap kepuasan konsumen membeli tiket pada agen jasa maskapai penerbangan PT. Garuda Airlines.
\end{abstract}

Kata Kunci: Kualitas Layanan, Kepuasan Konsumen

\section{PENDAHULUAN}

Saat ini penerbangan merupakan salah satu moda transportrasi yang sudah banyak digunakan oleh masyarakat. Hal ini dapat terjadi dikarenakan kebutuhan masyarakat akan transportasi untuk jarak jauh sudah cukup tinggi terlihat dari jumlah penumpang setiap penerbangan dalam maupun luar negeri. Selain itu harga dari moda transportasi penerbangan sudah terjangkau oleh masyarakat di Indonesia tidak seperti beberapa tahun silam, penerbangan merupakan salah satu moda transportasi yang memiliki harga yang cukup mahal.

Penerbangan tidaklah hanya sebuah moda transportasi biasa. Di dalam penerbangan terdapat juga jasa yang diberikan kepada para penumpang dan apabila kita berbicara mengenai jasa maka kita tidak akan bisa lepas untuk membahas mengenai pelayanan yang diberikan. Karena jasa sangat berhubungan erat dengan pelayanan, dengan kata lain di dalam penerbangan pelayanan merupakan hal yang sangat penting sebagai mana yang dikemukakan oleh Lupiyoadi dalam (Mongkaren,2013:495) 
bahwa kualitas layanan menjadi suatu keharusan yang harus dilakukan perusahaan supaya mampu bertahan dan tetap mendapat kepercayaan konsumen.

PT. Garuda Indonesia Airlines dalam menghadapi pesaing tidak terlalu takut dengan kebijakankebijakan para pesaingnya. Karena walaupun harga yang diberikan oleh maskapai Garuda Airlines bisa dikatakan relatif tinggi, Hal ini disebabkan karena perusahaan tersebut sudah memiliki standard Internasional dan persepsi masyarakatpun dapat dikatakan positif. Hal ini didukung berbagai pelayanan yang prima dan fasilitas yang modern serta ketetapan waktu dan empati sehingga dapat bertahan, bersaing dan menguasai pangsa pasar. Sehingga konsumen mendapatkan kepuasan dalam menggunakan jasa penerbangan Garuda Airlines. Sedangkan, untuk salah satu pesaingnnya yaitu maskapai Batik Air mereka juga memberikan pelayanan kepada para penumpangnya, tetapi tidak seperti maskapai Garuda yang memberikan layanan penuh.

Maskapai Garuda Airlines memberikan fasilitas dan pelayanan yang baik, maka maskapai ini selalu mendapat penghargaan. Seperti cabin crew terbaik dengan pelayanan yang baik. Maskapai ini sangat memperhatikan kenyamanan dan kepuasan dari konsumennya. Maka dari itu maskapai ini berbeda dibandingkan dengan pesaingnya Batik Air. Menurut Tjiptono ada lima dimensi yang berkaitan dengan kualitas jasa, yaitu bukti fisik, kehandalan, daya tanggap, jaminan dan empati.

Kualitas pelayanan yang baik erat hubungannya dengan kepuasan konsumen. Memberikan pelayanan yang baik kepada konsumen merupakan strategi yang harus dimiliki perusahaan guna memberikan kepuasan konsumen. Kualitas pelayanan merupakan tingkat keunggulan untuk memenuhi keinginan konsumen. Pada prinsipnya, setiap bisnis harus mampu memuaskan dan mempertahankan pelanggan. Kepuasan konsumen akan tercapai apabila kualitas produk atau jasa yang diberikan sesuai dengan kebutuhannya.

Berdasarkan uraian latar belakang di atas maka tujuan dari penelitian ini adalah untuk mengetahui dan menganalisis:

1. Pengaruh kualitas layanan yaitu: bukti fisik, kehandalan, daya tanggap, jaminan, empati terhadap kepuasan konsumen membeli tiket pada agen jasa maskapai PT. Garuda Airlines di Kota Palu.

2. Pengaruh bukti fisik terhadap kepuasan konsumen membeli tiket pada agen jasa maskapai PT. Garuda Airlines di Kota Palu.

3. Pengaruh kehandalan terhadap kepuasan konsumen membeli tiket pada agen jasa maskapai PT. Garuda Airlines di Kota Palu.

4. Pengaruh daya tanggap terhadap kepuasan konsumen membeli tiket pada agen jasa maskapai PT. Garuda Airlines di Kota Palu.

5. Pengaruh jaminan terhadap kepuasan konsumen membeli tiket pada agen jasa maskapai PT. Garuda Airlines di Kota Palu.

6. Pengaruh empati terhadap kepuasan konsumen membeli tiket pada agen jasa maskapai PT. Garuda Airlines di Kota Palu.

\section{KAJIAN LITERATUR DAN PENGEMBANGAN HIPOTESIS}

\section{Pengertian Manajemen Pemasaran}

Menurut Alma (2011:130) manajemen pemasaran ialah kegiatan menganalisa merencanakan mengimplementasikan dan mengawasi segala kegiatan (program) guna memperoleh tingkat pertukaran yang menguntungkan dengan pembeli sasaran dalam rangka mencapai tujuan organisasi.

\section{Pengertian Jasa}

Menurut Kotler dan Keller (2009:36) Jasa adalah setiap tindakan atau kinerja yang dapat ditawarkan satu pihak kepada pihak lain yang pada intinya tidak berwujud dan tidak menghasilkan kepemilikan apapun. Jasa dapat dikaitkan dengan produk fisik, tetapi biasa juga tidak dikaitkan. 


\section{Karakteristik Jasa}

Jasa memiliki beberapa karakterisik utama yang membedakannya dengan barang. Karakteristik jasa tersebut adalah (Kotler \& Keller, 2009:39):

1. Tak Berwujud

2. Tak Terpisahkan

\section{Bervariasi}

\section{Kategori Bauran Jasa}

Menurut Kotler and Keller (2009:38), komponen jasa bisa menjadi bagian kecil atau besar dari keseluruhan penawaran. Kami membedakannya menjadi 5 kategori penawaran:

1. Barang berwujud murni.

2. Barang berwujud yang disertai jasa.

3. Hibrida: penawaran terdiri dari bagian barang dan jasa yang sama proporsinya. Misalnya, orang sering mengunjungi restoran baik karena makanan maupun penyajiannya.

4. Jasa utama yang disertai barang dan jasa kecil.

5. Jasa murni penawaran murni terdiri dari jasa.

\section{Kualitas Layanan}

Menurut Wijaya (dalam Umbo dan Mandey 2014) mendefinisikan kualitas adalah merupakan ukuran sampai sejauh mana produk atau jasa sesuai kebutuhan, keinginan dan harapan para konsumen. Kualitas didasarkan pada pengalaman aktual pelanggan terhadap produk atau jasa yang diukur berdasarkan persyaratan-persyaratan tersebut.

\section{Kesenjangan Kualitas Pelayanan}

Menurut Kotler dan Keller (2009:51) model kualitas jasa menyoroti kebutuhan utama untuk menghantar kualitas jasa yang tinggi, model ini mengindetifikasi 5 kesenjangan yang menyebabkan kegagalan pengiriman jasa:

a. Kesenjangan antara harapan konsumen dan presepsi manajemen

b. Kesenjangan antara presepsi manajemen dan spesifikasi kualitas jasa

c. Kesenjangan antara spesifikasi kualitas jasa dan penghantaran jasa

d. Kesenjangan antara penghantaran jasa dan komunikasi eksternal

e. Kesenjangan anatara jasa anggapan dan jasa yang diharapkan

\section{Dimensi Kualitas Layanan}

Tjiptono (2005:14) mengemukakan bahwa dalam kualitas pelayanan ada beberapa dimensi atau atribut yang perlu diperhatikan yaitu:

1. Bukti Fisik/ yang berwujud merupakan suatu kondisi yang ada dalam memberikan pelayanan meliputi kualitas fisik, perlengkapan, pegawai, dan sarana komunikasi.

2. Empati meliputi kemudahan dalam melakukan hubungan, menjalin komunikasi yang baik dengan konsumen, perhatian pribadi dan memahami kebutuhan konsumennya dan memberikan perhatian yang tulus kepada konsumen.

3. Daya Tanggap merupakan suatu keinginan para staf untuk membantu konsumen, memberikan pelayanan yang tanggap, dan selalu ada disaat konsumen membutuhkan bantuan

4. Kehandalan merupakan suatu kemampuan memberikan pelayanan yang dijanjikan dengan segera, akurat dan memuaskan. Perusahaan yang baik akan memberikan pelayanan yang sesuai dengan apa yang telah dijanjikan dan mengatasi masalah konsumen melalui tindakan dan memberikan solusi yang tepat.

5. Jaminan mencakup pengetahuan, kemampuan, kesopanan dan sifat yang dapat dipercaya yang dimiliki oleh para staf, bebas dari bahaya, risiko dan keragu-raguan. 


\section{Kepuasan Konsumen}

Kotler (dalam Mongkaren 2013) mengatakan bahwa kepuasan konsumen adalah tingkat perasaan seseorang setelah membandingkan kinerja yang dirasakan dibandingkan dengan harapannya. Kepuasan adalah fungsi perbedaan antara kinerja yang dirasakan (perceived performance) dengan harapan (expeciations).

\section{Hubungan antara Kualitas layanan dan Kepuasan Konsumen}

Zeithmal, Parasuraman (dalam Suharso 2013) mendefinisikan kualitas pelanggan sebagai berikut: Kualitas layanan merupakan persepsi konsumen terhadap keunggulan layanan. Konsumen yang menilai kualitas layanan dari suatu badan usaha berkualitas atau tidak berkualitas, persepsi yang baik akan timbul jika konsumen memiliki pengalaman yang baik dan merasa puas terhadap kualitas layanan yang diberikan oleh suatu badan usaha.

\section{Kerangka Pemikiran}

Penelitian ini mengkaji lebih mendalam pengaruh kualitas layanan jasa maskapai penerbangan dengan menggunakan variabel kualitas layanan (Bukti Fisik, Empati, Kehandalan, Daya Tanggap, dan Jaminan) terhadap kepuasan konsumen membeli tiket pada agen jasa maskapai penerbangan PT. Garuda Airlines di Kota Palu. Agar dapat mempermudah penilaian pada perusahaan PT. Garuda Airlines di Kota Palu dalam pengukuran kualitas pelayanan dikembangkan suatu alat ukur kualitas layanan yang disebut SERVQUAL (service quality).

Agar lebih sederhana maka disusun suatu bagan kerangka pikir dalam penelitian ini yang digambarkan pada Gambar 1 berikut:

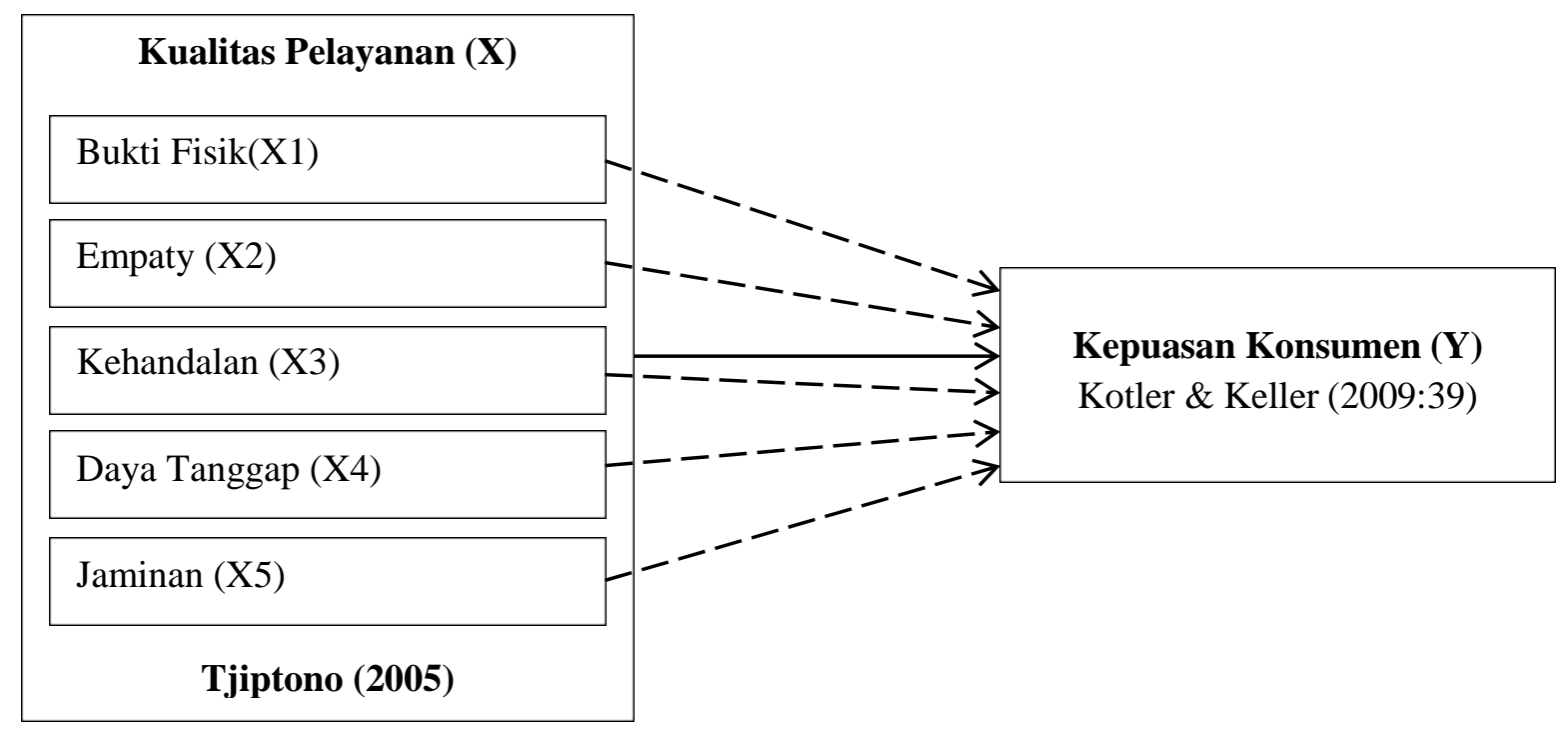

\section{Gambar 1 Kerangka Pemikiran}

\section{Hipotesis}

Berdasarkan uraian pada kerangka pemikiran yang telah diuraikan di atas dapat dikemukakan hipotesis dalam penelitian ini , sebagai berikut:

1. Kualitas layanan Bukti fisik, Empati, Kehandalan, Daya Tanggap, dan Jaminan secara serempak memengaruhi signifikan terhadap kepuasan konsumen membeli tiket pada agen jasa Maskapai Penerbangan PT. Garuda Airlines.

2. Variabel Bukti fisik memengaruhi kepuasan konsumen membeli tiket pada agen jasa maskapai penerbangan PT. Garuda Airlines. 
3. Variabel Empati memengaruhi kepuasan konsumen membeli tiket pada agen jasa maskapai penerbangan PT. Garuda Airlines.

4. Variabel Kehandalan memengaruhi kepuasan konsumen membeli tiket pada agen jasa maskapai penerbangan PT. Garuda Airlines.

5. Variabel Daya Tanggap memengaruhi kepuasan konsumen membeli tiket pada agen jasa maskapai penerbangan PT. Garuda Airlines.

6. Variabel Jaminan memengaruhi kepuasan konsumen membeli tiket pada agen jasa maskapai penerbangan PT. Garuda Airlines.

\section{METODE PENELITIAN}

Jenis penelitian yang digunakan adalah deskriptif kausal. Penelitian deskriptif digunakan dalam menggambarkan dan menganalisis hasil penelitian tetapi tidak digunakan dalam membuat kesimpulan yang lebih luas, (Sugiyono, 2014:30).

Lokasi penelitian yang akan dijadikan tempat penelitian adalah PT. Garuda Airlines di Jalan Juanda di Kota Palu. Data Primer, yaitu data yang penulis peroleh secara langsung dari sumbernya melalui observasi, wawancara, maupun daftar pertanyaan. Data Sekunder, yaitu data yang diperoleh secara tidak langsung, baik berupa keterangan maupun literatur yang ada hubungannya dengan penelitian. Dalam penelitian ini, mengingat subjek yang akan diteliti adalah responden yang tidak terorganisir (bias) dengan baik atau dengan kata lain tidak seperti karyawan, maka untuk mengumpulkan data dalam penelitian ini, peneliti menggunakan metode antara lain observasi, interview, dan angket.

Populasi dalam penelitian ini merupakan seluruh konsumen yang membeli tiket pada agen jasa maskapai penerbangan pada PT.Garuda Airlines di kota Palu. Bila dalam penelitian akan melakukan analisis multivariate (korelasi atau regresi ganda), maka jumlah anggota sampel minimal 10 kali dari jumlah variabel yang diteliti, yaitu $10 \times 6$ (variabel independen + variabel dependen) $=60$ orang sampel. Teknik penarikan sampel menggunakan metode purposive sampling. Metode purposive sampling menurut Sugiyono (2014:68) adalah tehnik penentuan sampel dengan pertimbangan tertentu. Adapun kriteria responden yang dijadikan sampel dalam penelitian ini adalah sebagai berikut:

1. Melakukan pembelian tiket penerbangan di PT. Garuda Airlines

2. Bersedia mengisi kuesioner

3. Pelanggan yang menggunakan jasa penerbangan PT. Garuda Airlines sebanyak dua kali.

Selanjutnya analisis data dilakukan secara deskriptif dan regresi. Model umum bentuk persamaan alat analisis statistik parametrik Regresi Linear Berganda dapat digambarkan sebagai berikut:

$$
\mathrm{Y}=\mathrm{a}+\mathrm{b} 1 \mathrm{X} 1+\mathrm{b} 2 \mathrm{X} 2+\ldots \ldots+\mathrm{bn} \mathrm{Xn}
$$

Bila formasi matematis Regresi Linear Berganda tersebut diaplikasikan dalam penelitian ini, maka akan diperoleh bentuk persamaan sebagai berikut:

$$
\mathrm{Y}=\mathrm{a}+\mathrm{b} 1 \mathrm{X} 1+\mathrm{b} 2 \mathrm{X} 2+\mathrm{b} 3 \mathrm{X} 3+\mathrm{b} 4 \mathrm{X} 4+\mathrm{b} 5 \mathrm{X} 5
$$

Dimana:

$\mathrm{Y}=$ Kepuasan Konsumen

a $\quad=$ Konstanta

$\mathrm{X} 1=$ Reliability

$\mathrm{X} 2=$ Responsiveness

$\mathrm{X} 3=$ Assurance

$\mathrm{X} 4=$ Empathy 
X5 = Tangible

$\mathrm{B} 1-\mathrm{b} 5=$ Parameter yang diukur

\section{Pengujian Hipotesis Pertama (Uji Serempak / Uji F)}

Uji F digunakan untuk mengetahui apakah seluruh variabel independen secara serempak mempunyai pengaruh yang signifikan terhadap variabel dependen.

1. Jika nilai uji $F$ (probability) $\leq(\alpha=0.05)$ artinya variabel $X$ berpengaruh signifikan terhadap variabel $\mathrm{Y}$, terbukti semua variabel independen yang diamati secara serempak berpengaruh signifikan terhadap variabel independen.

2. Jika nilai uji $F$ (probability) $>(\alpha=0.05)$ artinya variabel $X$ berpengaruh tidak signifikan terhadap variabel $\mathrm{Y}$, terbukti semua variabel independen yang diamati secara serempak tidak berpengaruh signifikan terhadap variabel dependen.

\section{Pengujian Hipotesis Kedua (Uji parsial / Uji t)}

Pengaruh masing-masing variabel independen secara parsial berpengaruh secara signifikan terhadap variabel independen dilakukan dengan pengujian uji-t, dimana derajat signifikan yang digunakan adalah $\alpha=0.05$ dengan bentuk pengujian sebagai berikut:

1. Jika nilai uji t (probability) $\leq(\alpha=0.05)$ artinya masing-masing variabel independen secara parsial berpengaruh signifikan terhadap kepuasan agen jasa penerbangan PT. Garuda Airlines di kota Palu.

2. Jika nilai uji $\mathrm{t}$ (probability) $>(\alpha=0.05)$ artinya variabel independen secara parsial berpengaruh tidak signifikan terhadap kepuasan agen jasa penerbangan PT. Garuda Airlines di kota Palu.

\section{HASIL DAN PEMBAHASAN}

Hasil Penelitian

Deskriptif Variabel Penelitian

Berdasarkan hasil jawaban responden untuk tiap variabel-variabel dari kualitas pelayanan dapat direkapitulasikan nilai mean dalam tabel di bawah ini.

Tabel 1 Rekapitulasi Nilai Mean

\begin{tabular}{|l|l|c|c|}
\hline No. & Variabel Independen & Mean & Peringkat \\
\hline 1. & Bukti Fisik (X1) & 3,94 & III \\
\hline 2. & Empati (X2) & 3,90 & V \\
\hline 3 & Kehandalan (X3) & 4,51 & I \\
\hline 4 & Daya Tanggap (X4) & 3,95 & II \\
\hline 5 & Jaminan (X5) & 3,92 & IV \\
\hline
\end{tabular}

Tabel di atas memberikan informasi bahwa variabel yang mememiliki nilai mean tertinggi adalah kehandalan sebesar 4,51. Kemudian peringkat kedua adalah variabel daya tanggap sebesar 3,95. Peringkat ketiga adalah variabel bukti fisik sebesar 3,94. Peringkat keempat adalah jaminan sebesar 3,92 dan yang memiliki nelai mean terendah adalah variabel daya tanggap sebesar 3,95.

\section{Hasil Analisis Regresi Linear Berganda}

Tabel 2 Hasil Regresi Linier Berganda

\begin{tabular}{|c|l|c|c|c|}
\hline No. & Variabel Independen & Koefisien Regresi & Uji t & Sig \\
\hline 1. & Bukti Fisik (X1) & 0,309 & 2,322 & 0,012 \\
\hline 2. & Empati (X2) & 0,112 & 1,870 & 0,045 \\
\hline 3 & Kehandalan (X3) & 0,465 & 3,820 & 0,002 \\
\hline 4 & Daya Tanggap (X4) & 0,226 & 2,138 & 0,019 \\
\hline 5 & Jaminan (X5) & 0,343 & 3,136 & 0,008 \\
\hline Konstanta & $=0,907$ & \\
\hline \multicolumn{4}{|l}{ Multiple R } & $=0,806$ \\
\hline
\end{tabular}


Hasil analisis regresi linier berganda dalam tabel di atas, kemudian dimasukkan ke dalam model persamaan Regresi Linear Berganda sebagai berikut:

$$
\mathrm{Y}=0,907+0,309 \mathrm{X} 1+0,112 \mathrm{X} 2+0,465 \mathrm{X} 3+0,226 \mathrm{X} 4+0,343 \mathrm{X} 5
$$

Nilai konstanta seperti yang ditunjukkan dalam tabel di atas sebesar 0,907 . Nilai positif konstanta tersebut memberikan arti bahwa jika kualitas layanannya yang terdiri dari bukti fisik, empati, kehandalan, daya tanggap, dan jaminan bernilai nol, maka kepuasan konsumen terhadap agen jasa maskapai penerbangan PT. Garuda Airlines sebesar 90,7\%.

Nilai koefisien regresi b1 $=0,309$ menunjukkan bahwa variabel Bukti Fisik (X1) berpengaruh positif terhadap kepuasan. Berarti bila Bukti Fisik ditingkatkan satu satuan sedangkan Empati, Kehandalan, Daya Tanggap, dan Jaminan diasumsikan tidak berubah/konstan (X2, X3, X4 dan X5 = 0) maka kepuasan akan meningkat sebesar $27,9 \%$.

Nilai koefisien regresi b2 $=0,112$ menunjukkan bahwa Empati (X2) berpengaruh positif terhadap kepuasan. Berarti bila Empati ditingkatkan satu satuan sedangkan Bukti Fisik, Kehandalan, DayabTanggap, dan Jaminan diasumsikan tidak berubah/konstan $(\mathrm{X} 1, \mathrm{X} 3, \mathrm{X} 4$ dan X5 = 0) maka kepuasan akan meningkat sebesar $11,1 \%$.

Nilai koefisien regresi b3 $=0,465$ menunjukkan bahwa variabel Kehandalan (X3) berpengaruh positif terhadap kepuasan. Berarti bila Kehandalan ditingkatkan satu satuan sedangkan Bukti Fisik, Empati, Daya Tanggap dan Jaminan diasumsikan tidak berubah/konstan (X1, X2, X4 dan X5 = 0) maka kepuasan akan meningkat sebesar 40,5\%.

Nilai koefisien regresi b4 $=0,226$ menunjukkan bahwa variabel Daya Tanggap (X4) berpengaruh positif terhadap kepuasan. Berarti bila Daya Tanggap ditingkatkan satu satuan sedangkan Bukti Fisik, Empati, Kehandalan, dan Jaminan diasumsikan tidak berubah/konstan $(\mathrm{X} 1, \mathrm{X} 2$, X3 dan X5 = 0) maka kepuasan akan meningkat sebesar $24 \%$.

Nilai koefisien regresi b5 $=0,343$ menunjukkan bahwa variabel Jaminan (X5) berpengaruh positif terhadap kepuasan. Berarti bila Jaminan ditingkatkan satu satuan sedangkan variabel Bukti Fisik, Empati, Kehandalan, dan Daya Tanggap diasumsikan tidak berubah/konstan (X1, X2, X3 dan X4 = 0) maka kepuasan pasien akan meningkat sebesar 36,6\%.

Adapun tingkat keeratan hubungan antara Bukti Fisik (X1), Empati (X2), Kehandalan (X3), Daya Tanggap (X4), Jaminan (X5) secara serempak dengan variabel kepuasan (Y) dapat dilihat nilai koefisien korelasi (Multiple R). Dari hasil analisis diperoleh nilai multiple $\mathrm{R}=0,806$ yang menunjukkan bahwa Bukti Fisik, Empati, Kehandalan, Daya Tanggap dan Jaminan memiliki hubungan yang sangat kuat dengan kepuasan. Hal ini berarti peningkatan Bukti Fisik, Empati, Kehandalan, Daya Tanggap dan Jaminan akan menyebabkan peningkatan yang sangat besar terhadap kepuasan.

Selanjutnya juga diperoleh nilai koefisien determinasi (adjusted $R$. Square) $=0,571$. Hasil ini menunjukkan bahwa perubahan Bukti Fisik, Empati, Kehandalan, Daya Tanggap dan Jaminan akan mempengaruhi $57,1 \%$ kepuasan pasien, dan sisanya yang sebesar $42,9 \%$ dipengaruhi oleh variabelvariabel lain yang tidak termasuk dalam penelitian ini.

\section{Hasil Pengujian Hipotesis \\ Hasil Pengujian Secara Serempak}

Pengujian hipotesis secara serempak, dimaksudkan untuk mengetahui apakah seluruh dimensi yang diangkat dalam penelitian yaitu Bukti Fisik, Empati, Kehandalan, Daya Tanggap dan Jaminan secara serempak berpengaruh terhadap Kepuasan (Y). Berdasarkan hasil penelitian yang dilakukan, nilai sig. F sebesar 0.000 yang lebih kecil dari $\alpha 0.05(0.000<\alpha 0.05)$. 


\section{Hasil Pengujian Secara Parsial}

Uraian hasil penelitian secara parsial dari kelima dimensi Kualita Layanan yaitu Bukti Fisik, Empati, Kehandalan, Daya Tanggap dan Jaminan dijelaskan sebagai berikut:

\section{Bukti Fisik (X1)}

Berdasarkan hasil pengujian menunjukkan nilai signifikansi sebesar $0.012<\alpha 0.05$. Hasil ini memberikan makna bahwa dimensi Bukti Fisik secara parsial memiliki pengaruh yang signifikan terhadap kepuasan.

\section{Empati (X2)}

Hasil pengujian sebagaimana pada Tabel di atas, menunjukkan bahwa nilai signifikansi sebesar 0,045 $<\alpha 0,05$. Hasil ini memberikan makna bahwa dimensi Empati secara parsial memiliki pengaruh yang signifikan terhadap kepuasan.

\section{Kehandalan (X3)}

Mengacu pada hasil penelitian Tabel di atas, menunjukkan bahwa nilai signifikansi sebesar $0,002>\alpha$ 0,05 . Hasil ini memberikan makna bahwa dimensi Kehandalan secara parsial berpengaruh signifikan terhadap kepuasan.

\section{Daya Tanggap (X4)}

Nilai Partial variabel Daya Tanggap $=0,042$ yang menunjukkan bahwa Daya Tanggap memiliki hubungan yang sangat rendah dengan kepuasan. Hal ini berarti peningkatan Daya Tanggap akan menyebabkan peningkatan yang biasa saja terhadap kepuasan.

Mengacu pada hasil penelitian Tabel di atas, menunjukkan bahwa nilai signifikansi sebesar 0,019 > $\alpha$ 0,05. Hasil ini memberikan makna bahwa dimensi Daya Tanggap secara parsial berpengaruh signifikan terhadap kepuasan.

\section{Jaminan (X5)}

Nilai Partial variabel Empati $=0,307$ yang menunjukkan bahwa Jaminan memiliki hubungan yang sedang dengan kepuasan. Hal ini berarti peningkatan Jaminan akan menyebabkan peningkatan yang biasa saja terhadap kepuasan.

Mengacu pada hasil penelitian Tabel di atas, menunjukkan bahwa nilai signifikansi sebesar 0,008 $>\alpha$ 0,05 . Hasil ini memberikan makna bahwa dimensi Jaminan secara parsial berpengaruh signifikan terhadap kepuasan.

\section{Pembahasan}

\section{Pengaruh Kualitas Pelayanan Terhadap Kepuasan Konsumen}

Kualitas pelayanan yang baik di dalam suatu perusahaan, akan menciptakan kepuasan bagi para konsumennya. Setelah konsumen merasa puas dengan produk atau jasa yang diterimanya, konsumen akan membandingkan pelayanan yang diberikan. Apabila konsumen merasa benar-benar puas, mereka akan membeli ulang serta memberi rekomendasi kepada orang lain untuk membeli di tempat yang sama. Oleh karena itu perusahaan harus memulai memikirkan pentingnya pelayanan pelanggan secara lebih matang melaui kualitas pelayanan, karena kini semakin disadari bahwa pelayanan (kepuasan pelanggan) merupakan aspek vital dalam rangka bertahan dalam bisnis dan memenangkan persaingan.

Hasil penelitian ini sejalan dengan hasil penelitian yang dilakukan oleh Wendha et all (2013) yang mendapatkan hasil bahwa kualitas pelayanan berpengaruh signifikan terhadap kepuasan konsumen. Penelitian yang dilakukan oleh Lubis (2013) dan Syamsi (2008) juga menyimpulkan bahwa kualitas pelayanan berpengaruh signifikan terhadap kepuasan konsumen. 


\section{Bukti Fisik}

Suatu bentuk jasa tidak bisa dilihat, tidak bisa dicium dan tidak bisa diraba maka aspek wujud fisik menjadi penting sebagai ukuran dari pelayanan. Pelanggan akan menggunakan indera penglihatan untuk menilai suatu kulitas pelayanan.

Bukti fisik yang baik akan mempengaruhi persepsi pelanggan. Pada saat yang bersamaan aspek ini juga merupakan salah satu sumber yang mempengaruhi harapan pelanggan. Karena dengan bukti fisik yang baik maka harapan konsumen menjadi lebih tinggi. Oleh karena itu merupakan hal yang penting bagi perusahaan untuk mengetahui seberapa jauh aspek wujud fisik yang paling tepat, yaitu masih memberikan impresi positif terhadap kualitas pelayanan yang diberikan tetapi tidak menyebabkan harapan pelanggan yang terlalu tinggi sehingga dapat memenuhi kebutuhan konsumen dan memberikan kepuasan kepada konsumen.

Bukti fisik Agen jasa penerbangan PT. Garuda Indonesia Airlines dapat dilihat dari gedung yang digunakan cukup nyaman ketika membeli tiket. Di dalam gedung dilengkapi pendingin ruangan, televisi agar calon pembeli tiket tidak merasa bosan saat menunggu antrian membeli tiket. Agen jasa penerbangan PT. Garuda Indonesia Airlines memberikan informasi keberangkatan dan kedatangan penerbangan serta tujuan keberangkatan dengan jelas. Agen jasa penerbangan PT. Garuda Indonesia Airlines juga menyediakan beberapa fasilitas seperti toilet yang memiliki perlengkapan yang cukup seperti tisu dan sabun. Disamping itu Agen jasa penerbangan PT. Garuda Indonesia Airlines menyediakan area parkir yang cukup luas.

Berdasarkan hasil penelitian diketahui bahwa bukti fisik memberikan pengaruh signifikan terhadap kepuasan konsumen membeli tiket pada agen jasa maskapai penerbangan PT. Garuda Airlines. Hasil penelitian ini sejalan dengan penelitian yang dilakukan Wendha et all (2013), yang menyatakan bahwa bukti fisik memberikan pengaruh signifikan terhadap kepuasan konsumen. Semakin baik persepsi konsumen terhadap wujud fisik maka kepuasan konsumen juga akan semakin tinggi. Dan jika persepsi konsumen terhadap wujud fisik buruk maka kepuasan konsumen juga akan semakin rendah.

\section{Empati}

Empati yaitu perhatian dengan memberikan sikap yang tulus dan berifat individual atau pribadi yang diberikan perusahaan kepada pelanggan seperti kemudahan untuk menghubungi perusahaan, kemampuan karyawan untuk berkomunikasi dengan pelanggan dan usaha perusahaan untuk memahami keinginan dan kebutuhan pelanggan. Dimana suatu perusahaan diharapkan memiliki pengertian dan pengetahuan tentang pelanggan, Memahami kebutuhan pelanggan secara spesifik, serta memiliki waktu pengoperasian yang nyaman bagi pelanggan.

Empati agen jasa maskapai penerbangan PT. Garuda Airlines dapat terlihat dari perhatian karyawan menangani konsumen, kesopanan karyawan/karyawati, kesungguhan karyawan dalam menangani keluhan konsumen dan kecepatan karyawan/karyawati dalam melayani konsumen.

Berdasarkan hasil penelitian diketahui bahwa empati memberikan pengaruh signifikan terhadap kepuasan konsumen membeli tiket pada agen jasa maskapai penerbangan PT. Garuda Airlines. Hasil penelitian ini didukung penelitian yang dilakukan Wendha et all (2013), yang menyatakan bahwa empati memberikan pengaruh signifikan terhadap kepuasan konsumen.

\section{Kehandalan}

Kehandalan Agen jasa penerbangan PT. Garuda Indonesia Airlines selaku perusahaan yang mengelola jasa memberikan pelayanan dengan akurat dan terpercaya sesuai dengan harapan konsumen/pelanggan,serta pelayanan yang sama bagi semua konsumen/pelanggan dan tanpa kesalahan. Karyawan berusaha membangun komunikasi yang baik dengan konsumen sehingga tercipta hubungan baik. Pada penelitian ini, dimensi kehandalan berpengaruh signifikan terhadap kepuasan konsumen membeli tiket pada agen jasa maskapai penerbangan PT. Garuda Airlines. Hal tersebut disebabkan oleh kemampuan kayawan dan perusahaan untuk berusaha menjadi terpercaya bagi 
konsumen dengan cara memberikan pelayanan yang baik serta berusaha membangun kepercayaan yang berfokus pada kepuasan pelanggan. Hasil penelitian ini sejalan dengna penelitian yang dilakukan Lubis (2013) yang menyatakan bahwa kehandalan berpengaruh signifikan terhadap kepuasan pelanggan arumas Hotel Lubuk Sikamping.

\section{Daya Tanggap}

Daya tanggap yaitu respon atau kesigapan karyawan dalam membantu pelanggan dan memberikan pelayanan yang cepat dan tangap, yang meliputi kesigapan karyawan dalam melayani pelanggan, kecepatan karyawan dalam menangani transaksi serta penanganan keluhan pelanggan. Semakin baik persepsi konsumen terhadap daya tanggap perusahaan maka kepuasan konsumen juga akan semakin tinggi. Dan jika persepsi konsumen terhadap daya tanggap buruk maka kepuasan konsumen juga akan semakin rendah.

Daya tanggap Agen jasa penerbangan PT. Garuda Indonesia Airlines selaku perusahaan yang mengelola jasa memberikan pelayanan yang tepat dan cepat (responsif) kepada para konsumen/pelanggan sehingga menimbulkan kepercayaan dan keyakinan bagi para konsumen/pelanggan. Karyawan berusaha tanggap dalam menyelesaikan keluhan konsumen. Dengan adanya daya tanggap dari karyawan maka konsumen merasa diperhatikan. Hasil penelitian ini sejalan dengan hasil penelitian yang dilakukan oleh Syamsi (2008) yang menyatakan bahwa daya tanggap berpengaruh signifikan terhadap kepuasan konsumen pada siswa bimbingan dan konsultasi belajar AlQolam Bandar Lampung.

\section{Jaminan}

Jaminan meliputi kemampuan karyawan atas pengetahuannya terhadap produk secara tepat, keramahtamahan, perhatian dan kesopanan, ketrampilan dalam memberikan informasi, kemampuan dalam memberikan keamanan dalam memanfaatkan jasa yang ditawarkan dan kemampuan dalam menanamkan kepercayaan pelanggan terhadap perusahaan, sifat dapat dipercaya yang dimiliki para staf, bebas dari bahaya, resiko atau pun keraguan. Pengetahuan, kesopansantunan, dan kemampuan para pegawai perusahaan dapat menumbuhkan rasa percaya para pelanggan kepada perusahaan.

Jaminan Agen jasa penerbangan PT. Garuda Indonesia Airlines selaku perusahaan yang mengelola jasa menimbulkan keyakinan dan kepercayaan terhadap janji yang telah diucapkan kepada konsumen/pelanggan. Dimana agen memberikan jaminan keselamatan penerbangan kepada para konsumen. Disamping itu pihak penerbangan PT. Garuda Indonesia Airlines akan memberikan ganti rugi apabila pesawat mengalami keterlambatan penerbangan. Hasil penelitian ini sejalan dengan hasil penelitian yang dilakukan oleh Syamsi (2008) yang menyatakan bahwa jaminan berpengaruh signifikan terhadap kepuasan konsumen pada siswa bimbingan dan konsultasi belajar Al-Qolam Bandar Lampung.

\section{KESIMPULAN DAN SARAN}

\section{Kesimpulan}

Berdasarkan hasil penelitian dan pembahasan sebagaimana telah diuraikan, maka kesimpulan yang dapat ditarik pada penelitian ini yaitu:

1. Dimensi kualitas layanan yang terdiri dari Bukti Fisik, Empati, Kehandalan, Daya Tanggap, dan Jaminan secara serempak berpengaruh signifikan terhadap kepuasan konsumen membeli tiket pada agen jasa maskapai penerbangan PT. Garuda Airlines.

2. Dimensi Bukti Fisik berpengaruh signifikan terhadap kepuasan konsumen membeli tiket pada agen jasa maskapai penerbangan PT. Garuda Airlines.

3. Dimensi Empati berpengaruh signifikan terhadap kepuasan konsumen membeli tiket pada agen jasa maskapai penerbangan PT. Garuda Airlines. 
4. Dimensi Kehandalan berpengaruh signifikan terhadap kepuasan konsumen membeli tiket pada agen jasa maskapai penerbangan PT. Garuda Airlines.

5. Dimensi Daya Tanggap berpengaruh signifikan terhadap kepuasan konsumen membeli tiket pada agen jasa maskapai penerbangan PT. Garuda Airlines.

6. Dimensi Jaminan berpengaruh signifikan terhadap kepuasan konsumen membeli tiket pada agen jasa maskapai penerbangan PT. Garuda Airlines.

\section{Saran}

Berdasarkan kesimpulan yang telah diuraikan sebelumnya, maka saran-saran yang tepat menyangkut penelitian ini dapat diuraikan sebagai berikut:

1. Kepada manajemen agen jasa maskapai penerbangan PT. Garuda Airlines sebaiknya melakukan renovasi ruang tunggu guna meningkatkan kepuasan konsumen.

2. Kepada manajemen agen jasa maskapai penerbangan PT. Garuda Airlines sebaiknya memberikan rasa nyaman kepada konsumen saat membeli tiket.

3. Kepada manajemen agen jasa maskapai penerbangan PT. Garuda Airlines sebaiknya membuka pembelian tiket sesuai dengan jadwal yang tertera sehingga konsumen tidak perlu menunggu dalam waktu yang lama.

4. Kepada manajemen agen jasa maskapai penerbangan PT. Garuda Airlines sebaiknya memberikan yang cepat terhadap keluhan konsumen.

5. Memberikan keamanan pada kendaraan konsumen saat parkir.

6. Kepada peneliti selanjutnya disarankan untuk memasukkan variabel lain, selain yang digunakan dalam penelitian ini sehingga lebih dapat mengukur sebab-sebab yang mempengaruhi kepuasan, selain itu juga diharapkan untuk menggunakan ukuran sampel yang lebih besar dari jumlah sampel yang digunakan pada penelitian ini sehingga keakuratan hasil penelitian akan lebih terjamin.

\section{REFERENSI}

Alma, Buchari. (2011). Manajemen Pemasaran dan Pemasaran Jasa. Edisi Revisi. Bandung: Alfabeta.

Ghozali, Imam. (2005). Aplikasi Analisis Multivariate dengan Program SPSS. Semarang: Badan Penerbit Universitas Diponegoro.

Kotler, Philip dan Kevin Lane Keller. (2009). Manajemen Pemasaran: Jilid I. Jakarta: Erlangga.

----. (2009). Manajemen Pemasaran: Jilid II. Jakarta: Erlangga.

Lubis, M. Saleh. (2013). Pengaruh kualitas pelayanan terhadap kepuasan Pelanggan arumas hotel lubuk sikaping: e-Jurnal Apresiasi Ekonomi Vol 1, No 2, Mei 2013 : 77-85.

Mongkaren, Steffi. (2013). Fasilitas Dan Kualitas Pelayanan Pengaruhnya Terhadap Kepuasan Penguna Jasa Rumah Sakit Advent Manado: Jurnal EMBA. Vol.1 No.4 Desember 2013, Hal. 493503

Suharso, Edwin Sugito (2013). Pengaruh Kualitas Layanan Terhadap Kepuasan Pelanggan dalam Membentuk Loyalitas Pelanggan Pada Bengkel Resmi Yamaha CV. Saranan Makmur Sejahtera (SMS) Motor di Surabaya: Jurnal ilmiah Mahasiswa Universitas Surabaya Vol. 2 No. 2, Hal:1-12

Sugiyono. (2014). Metode penelitian kuantitatif Kualitatif dan $R \& D$. Bandung: Alfabeta.

Syamsi (2008). Pengaruh Kualitas Pelayanan Jasa Tehadap Kepuasan Konsumen Pada Siswa Bimbingan Dan Konsultasi Belajar Al Qolam Bandarlampung. Jurnal Ekonomi \& Pendidikan, Volume 5 Nomor 1, April 2008, Hal: 18-36.

Tjiptono, Fandy. (2005). Prinsip-Prinsip Total Quality Service. Yogyakarta: Andi.

Umboh, J Valdo, dan Silvya L Mandey (2014). Analisis kualitas jasa layanan pengaruhnya terhadap kepuasan nasabah pada PT. pengadaian (persero) cabang teling: Jurnal EMBA Vol.2 No 3 september 2014, hal 654-663. 
Puspitasari, H.

Wendha, A.A Ayu Atika Paramitha, I Ketut Rahyuda dan I Gst .A. Kt G . Suarsana, (2013). Pengaruh Kualitas Pelayanan terhadap kepuasan dan Loyalitas Pelanggan Garuda Indonesia Di Denpasar: Jurnal Manajemen, Strategi Bisnis, dan Kewirausahaan Vol. 7, No.1, Februari 2013. 